\title{
Research on the High-skilled Talent-training Mode for the Computer Network Technology in Higher Vocational Education
}

\author{
Hui Suo ${ }^{1, a}$ and Caijuan Huang, ${ }^{1, *}$ \\ ${ }^{1}$ Guangdong Mechanical and Electrical College, Guangzhou, 510515, China \\ asuohui79@163.com \\ "Corresponding author, 76485256@qq.com
}

Keywords: Talent-training mode; Computer network technology; Higher vocational education

\begin{abstract}
Recently, the development of network technologies such as e-commerce and mobile Internet brings new challenges for the talent-training of the computer network technology in higher vocational education. This article first in brief introduces the industry background and then analyzes the talent demand for the computer network technology. And on the basis of this, the article will deeply research on the high-skilled talent-training mode for the computer network technology in higher vocational education from five aspects: optimizing talent-training scheme, deepening the school-enterprise cooperation, combining skill certificates and skill competitions and combining instruction and learning, strengthening the innovative education.
\end{abstract}

\section{Introduction}

In recent years, with the fast development of the computer network technology, more and more enterprises begin to set up their own local area network, and gradually put the business in the network and depend on the network, which will bring the talent demand for computer network technology. And this will put forward new requirement of talent-training model for the computer network technology, especially for skilled talents of computer network technology in higher vocational education.

This article will research on the high-skilled talent-training model for the computer network technology in higher vocational education in the current environment. The rest of this article is organized as follows: Section I shows the talent demand of the computer network technology in high vocational education. Section II presents the high-skilled talent-training mode from five aspects. Section III concludes the whole paper.

\section{The Talent Demand of the Computer Network Technology in Higher Vocational Education}

Jobs Demand. As mentioned above more and more enterprises need the high-skilled talent of computer network technology. Based on the jobs that the enterprises provide we carried on the investigation and analysis. The analysis results show that the talent demand associating with the computer network technology is mainly divided into four categories: information system integration, network management and system maintenance, web application development and E-commerce operations. The specific jobs are mainly system administrator, network engineer, technical support engineer, virtualization and cloud computing engineer, front-end developer, system integration engineer, desktop support engineer, web site development engineer, network administrator, E-business operation assistant, SEOer and so on.

Skills Demand. Companies generally think that of computer network technology must have ability to configure the network device, manage and maintenance the network, configure the operating system, manage the web site and web server, manage database server, maintenance the network security and system security. In addition, the graduates also need to master the skill for virtualization, cloud computing and Internet of things etc.

Professional Qualities Demand. When the companies employ the graduates, they will pay attention to the professional qualities including professional ethics, team consciousness, innovative ability, communication skills etc. and the companies will pay more attention to the comprehensive qualities of 
skilled talents, such as the daily development of the professional ability and the ability to learn in the process of talent training.

For convenience, Table 1 presents a summary of talent demand analysis of the computer network technology in higher vocational education.

Table 1 A summary of talent demand analysis of the computer network technology

\begin{tabular}{|c|c|c|c|}
\hline \multicolumn{2}{|r|}{ Jobs Demand } & Skills demand & $\begin{array}{c}\text { Professional } \\
\text { aualities demand }\end{array}$ \\
\hline \multirow[b]{2}{*}{$\begin{array}{l}\text { Information } \\
\text { system } \\
\text { integration }\end{array}$} & $\begin{array}{l}\text { Technical } \\
\text { engineer }\end{array}$ & $\begin{array}{l}\text { To configure the network } \\
\text { device } \\
\text { To manage and maintenance } \\
\text { the network }\end{array}$ & \multirow{10}{*}{$\begin{array}{l}\text { Professional ethics } \\
\text { Team } \\
\text { consciousness } \\
\text { Innovative ability } \\
\text { Communication } \\
\text { skills } \\
\text { The ability to learn }\end{array}$} \\
\hline & $\begin{array}{l}\text { System } \\
\text { engineer }\end{array}$ & $\begin{array}{l}\text { To configure the operating } \\
\text { system } \\
\text { To master the cloud computing } \\
\text { and } \\
\text { To master the skill for } \\
\text { virtualization, cloud computing } \\
\text { and Internet of things etc. }\end{array}$ & \\
\hline \multirow{4}{*}{$\begin{array}{l}\text { Network } \\
\text { management } \\
\text { and system } \\
\text { maintenance }\end{array}$} & Network administrator & \multirow{3}{*}{$\begin{array}{l}\text { To configure the network } \\
\text { device } \\
\text { To manage and maintenance } \\
\text { the network } \\
\text { To manage the desktop } \\
\text { To maintenance the network } \\
\text { security and system security }\end{array}$} & \\
\hline & Network engineer & & \\
\hline & Desktop support engineer & & \\
\hline & System administrator & $\begin{array}{l}\text { To configure the operating } \\
\text { system } \\
\text { To manage the web site and } \\
\text { web server } \\
\text { To manage database server } \\
\text { To maintenance the system } \\
\text { security }\end{array}$ & \\
\hline \multirow{2}{*}{$\begin{array}{l}\text { Web } \\
\text { application } \\
\text { development }\end{array}$} & Front-end developer & To develop the web front-end & \\
\hline & $\begin{array}{l}\text { Web site development } \\
\text { engineer }\end{array}$ & To develop the web site & \\
\hline \multirow{2}{*}{$\begin{array}{l}\text { E-commerce } \\
\text { operations }\end{array}$} & $\begin{array}{l}\text { E-business Operation } \\
\text { Assistant }\end{array}$ & \multirow{2}{*}{ To make network marketing } & \\
\hline & SEOer & & \\
\hline
\end{tabular}

\section{The High-skilled Talent-training Mode for the Computer Network Technology in Higher Vocational Education}

Based on the above talent demand analysis, it can be seen that the development of the Internet puts forward higher requirements for the high-skilled talent-training in higher vocational education. Therefore it is imperative to research on the high-skilled talent-training mode for computer network technology. In this section, we will discuss the high-skilled talent-training mode from the following five aspects.

Adapting to the Demands of Industrial Upgrading, Optimizing Talent-training Scheme. Industrial upgrading will put forward higher demand to talent training in higher vocational education, so optimizing talent-training scheme is very imperative. Firstly, we determine the job demand and analyze job characteristics based on the talent demand analysis. Then we make the ability goals of courses 
according to the ability goals of the jobs, thus form a complete curriculum system based on the talent demand. On the basis of this, we further optimize talent-training scheme and determine the training objectives, which makes the students to be high-skilled talent engaging in network technology, at the same time have good professional ethics, good communication ability, self-learning ability etc.

Deepening the School-enterprise Cooperation. Specialty construction should be based on the requirement of the enterprise in higher vocational education, so deepening the school-enterprise cooperation is a good way to train the high-skilled talent, which can make school to understand the actual talent demand of the enterprise and help the students to adapt to the enterprise environment as soon as possible.

Firstly, school and enterprises develop curriculum standard and research teaching methods and evaluation standards and then make the talent training scheme together. Secondly the school selects some backbone teachers to participate in the research of enterprises or train staff for the enterprise. In this way, the teachers will be able to keep up with the technological frontier and master the latest technology. Thirdly, the enterprises select technical personnel to become part-time teachers of the school, in order that the students will be able to master the technology that the enterprises need. In addition, school and enterprises co-build training rooms and participate in enrollment plan or daily behavior management.

Deepening the school-enterprise cooperation will be able to shorten the distance between school and enterprise, and improve the students' ability to adapt to the enterprises, so that the students will be qualified for their jobs quickly.

Combining Skill Certificates and Skill Competitions. To improve students' learning initiative, we combine skill certificates and skill competitions in the teaching process. In the class, the teaching content includes the content of the skill certificates and skill competitions, especially the design of the experiment project can improve the level of students' skills and knowledge. At the same time, according to their own interest, we divide students into different extracurricular interest groups outside the class. Each group has its own study task, such as the computer network application competition, information security technology competition, network engineer certificate and so on.

Preparation for skill certificates and participation in the process of skills competitions exercise the students' learning ability, handling ability and team communication ability. At the same time, the students who obtain certificates or awards can enhance their self-confidence, and get a good preparation for employment.

Combining Instruction and Learning. In the current computer network environment, the students' self-study ability is more important, therefore, combining instruction and learning is an efficient way to improve students' autonomous learning ability. On the one hand, the instruction of the teachers can from the following several aspects to consider. Firstly, teachers can design the guiding cases and implement the combining of teachers guiding and students learning in the class. Secondly, teachers can construct extracurricular interest groups, and by this means students can keep up with the guiding of the teachers. Thirdly, teachers can give students a lot of online course resources for the use of students' self-study. On the other hand, students should complete the preparation before the class according to the teacher's guidance including knowledge and skill of the course content in a number of ways, and form the self-study report through analyzing, then actively cooperate with the teacher in the class to complete the course. Students still can select their interesting groups and complete self-study according to the guidance and the online course resources provided by teachers.

Combining instruction and learning improves the ability to learn and students' self-confidence and comprehensive quality.

Strengthening the Innovative Education. The innovation ability and innovative consciousness are very important for the enterprise, so we need to strengthen the cultivation of innovation ability. First of all, we can carry out the innovation education in the form of project training and optional course. Then we should improve teachers' ability of innovation, and the teachers take the concept of innovation throughout the whole teaching process. 
Above all, we first analyze the talent demand, and then we propose the high-skilled talent-training mode in order to achieve the training objectives. It is illustrated in Fig. 1.

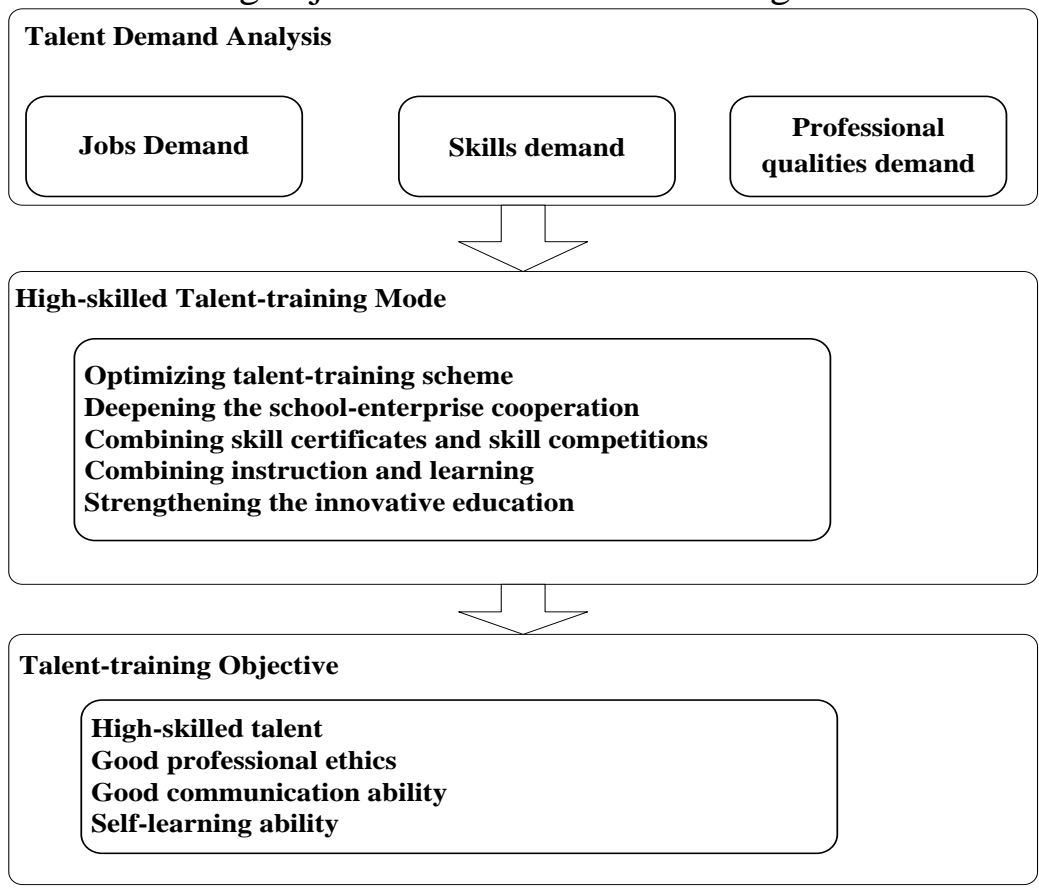

Figure 1. High-skilled Talent-training Mode

\section{Summary}

In this paper, we analyzed the talent demand of the computer network technology from three aspects: job demand, skill demand and professional qualities demand, and discussed the high-skilled talent-training for the computer network technology in high vocational education. The higher vocational education will face the new tasks and challenges. In order to make students to adapt to enterprise environment and competent for jobs, we must constantly explore and update talent-training mode and teaching method. On the one hand, we should improve students' job skills; on the other hand, we should strengthen the development of quality education and learning ability, enables students to keep up with the technology development and meet the needs of enterprises.

\section{Acknowledgements}

This research was financially supported by the Science Foundation for The Excellent Youth Scholars Training and Calculation of Guangdong Province (Yq2013171).

\section{References}

[1] Suo Hui, Liu Zhuohua, Exploring on the skill talent-training mode for the computer network Technology in Higher Vocational Education in " Internet +" Environment, Fujian Computer. 2016.11, pp. 68-69.

[2] Huang Zhiguang, LIU Xiao-mei ,On the Methods for Cultivating Innovative People. Journal of Graduate Education, 2007.04.

[3] Ding Xiao-xiang, Reseach on the skill talent-training mode for the computer network technology, Technology Wind, 2016.4, pp. 128.

[4] Zeng Na, Exploration and practice on the talent training mode reform for the computer network technology, Occupation,2015.03,pp. 34-35 